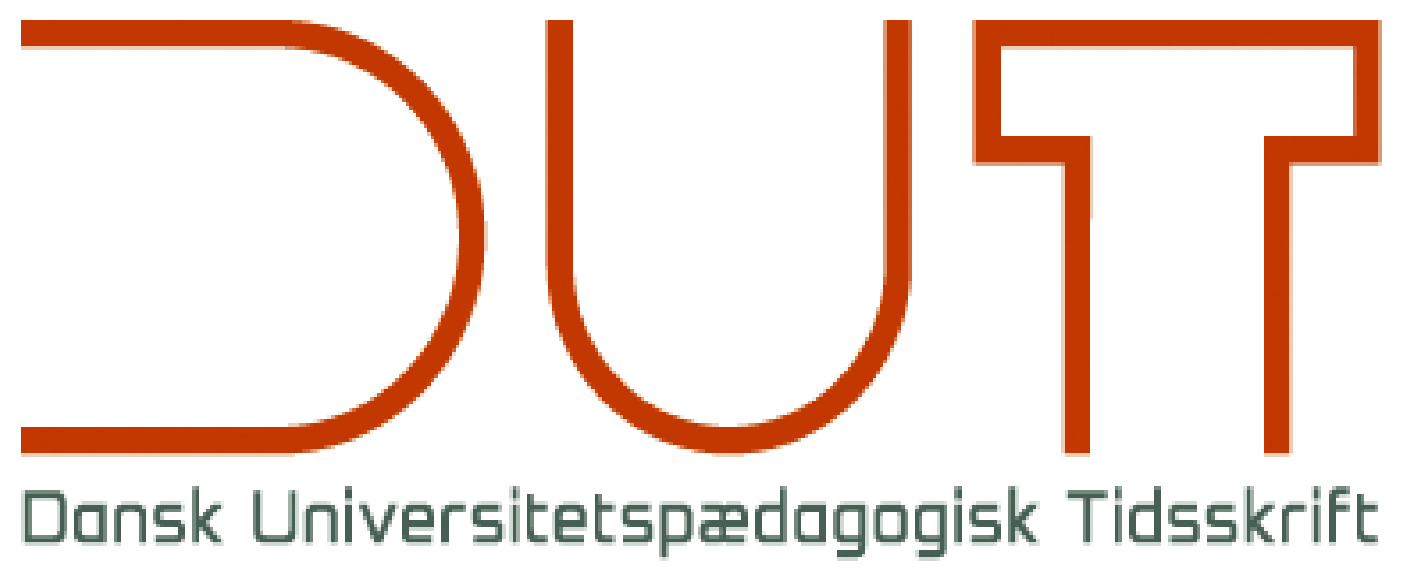

Tema

Fra data til beslutninger

Årgang 14 nr. 26 / 2019

Titel

A flowchart as a tool to support student learning in a laboratory exercise

Forfattere

Sidetal

Dominik K. Grosskinsky, Katrin Hammer úr Skúoy, Kirsten Jørgensen

23-35

Udgivet af

Dansk Universitetspædagogisk Netværk, DUN

URL

> http://dun-net.dk/

Betingelser for brug af denne artikel

(C) Copyright
Denne artikel er omfattet af ophavsretsloven, og der må citeres fra den. Følgende betingelser skal dog være opfyldt:

- Citatet skal være i overensstemmelse med "god skik"

- Der må kun citeres „i det omfang, som betinges af formålet"

- Ophavsmanden til teksten skal krediteres, og kilden skal angives ift. ovenstående bibliografiske oplysninger.

DUT og artiklens forfatter 


\title{
A flowchart as a tool to support student learning in a laboratory exercise
}

\author{
Dominik K. Grosskinsky ${ }^{\mathrm{a}, 1}$, Katrin Hammer úr Skúoy ${ }^{\mathrm{b}}$, Kirsten Jørgensen ${ }^{\mathrm{c}}$ \\ a,cDepartment of Plant and Environmental Sciences, University of Copenhagen, ${ }^{b}$ Department of Science \\ Education, University of Copenhagen
}

Practice paper, peer-reviewed

\begin{abstract}
Practical laboratory exercises are an essential part of university education in natural sciences. However, the multitude of positive aspects of this active and lively teaching approach is accompanied by some challenges, which have to be considered by the teacher(s) of practical exercises. In this project, a strategy was designed, employed, and evaluated to support teaching and student learning in laboratory exercises spread over several days by implementing a flowchart as a central component. Initial coconstruction of the flowchart with the students gives ownership of the exercise to the students and forms a common basis for communication and interaction as well as a point of reference throughout the exercise. This approach supported student learning as evidenced by increased understanding of the content and the ability to connect individual parts of the exercise. In addition, it allows the teacher to easily track student progress.
\end{abstract}

\section{Introduction}

In natural sciences, practical exercises, including laboratory work, are a central part of student education (Hofstein \& Lunetta, 2004; Reid \& Shah, 2007). Even though aspects such as level of education, e.g., BSc vs. MSc studies, and the specific discipline affect the design of meaningful practical laboratory exercises (Hofstein \& Lunetta, 2004; Hofstein \& MamlokNaaman, 2007), they are generally a suitable approach to combine various positive aspects. Students get the chance to connect theoretical knowledge with practical applications, and subsequently, may better internalize theoretical knowledge. In addition, students have the indispensable opportunity to gain hands-on experience in important methods they may need to address scientific questions later in their career. Finally, it is a good way to diversify teaching beyond lecturing and other theoretical teaching approaches, which appear to be beneficial per se for diverse learners (Tanner \& Allen, 2004).

Planning and running practical laboratory exercises in natural sciences can be challenging, especially when working with biological systems, which often are relatively complex. Experimental work can be lengthy, which means that individual work steps have to be spread over several days. This increases the students' challenge of following and connecting different work steps and thus, the teachers' challenge of efficiently supporting student learning. The students' development in the context of the learning goals of the course, their awareness of the current status of their work, and their understanding of the dynamically

\footnotetext{
${ }^{1}$ Contact: dkg@plen.ku.dk
} 
developing content have to be observed and supported over several days. Therefore, reliable and efficient tools to help a teacher cope with these challenges in class to maintain a positive and supportive learning environment for students are very valuable.

Flowcharts are tools to visually break down complex information into individual building blocks and how the blocks are connected. In practical exercises in natural sciences, complex experimental approaches could be represented by connected sequences of individual work steps and several parallel approaches may be interlinked at different levels of such a flowchart. The visual breakdown facilitates the accessibility of information and could, therefore, support student understanding of experimental procedures and link them to theoretical knowledge (Davidowitz \& Rollnick, 2001). They can be used to prepare students for the laboratory work and encourage them to read instructions (Davidowitz \& Rollnick, 2001). Following a suitable implementation strategy, which contains aspects of knowledge integration and monitoring, flowcharts can be a teacher's tool in laboratory teaching to enhance students' metacognitive learning (Davidowitz \& Rollnick, 2003). In addition, flowcharts seem to be well appreciated by students in natural science laboratory exercises (Davidowitz \& Rollnick, 2003). Thus, flowcharts can be useful to support students' understanding of the content of an exercise and their progress in the practical work.

The implementation of a flowchart for a practical laboratory exercise in plant science at BSc level is presented here. The outline of the flowchart is pre-designed and further construction is performed in class in cooperation with the students. This concept was specifically tailored to the respective teaching unit and was designed within the framework of a teaching development project as part of a university pedagogical education program. The implementation of the flowchart is aimed at preparing the students for the individual work steps, giving them a framework for connecting individual work steps and sequences, and being able to evaluate the results. For the teacher, different activities composed in an implementation plan should simultaneously serve the purpose of tracking the development of the students, providing regular feedback and flexibly reacting to the needs of the students, guiding them through the exercise. Furthermore, the flowchart should serve as a basis for teacher-student communication, in which different ways of using the flowchart should contribute to diversifying the classroom by giving changing roles to the teacher and students (Beck \& Gottlieb, 2002). All these aspects should contribute to improving student learning in this practical exercise.

\section{Setup and Methodology}

The presented teaching approach was implemented in the laboratory exercise "Tracking Gene Expression," which was part of the course Plant Genomics in 2017. This course is embedded in the BSc programs in Biology-Biotechnology and Natural Resources at the Department of Plant and Environmental Sciences at the University of Copenhagen. Eleven students in their $2^{\text {nd }}$ or $3^{\text {rd }}$ year of BSc studies participated. For the laboratory exercise, the students were divided into four groups (three groups of three students, one group of two students). The presented teaching approach was implemented as a project to improve student learning (Grosskinsky, 2018) as part of the teacher's pedagogical education (Teaching and Learning in Higher Education Program/Universitetspædagogikum; Department of Science Education, University of Copenhagen), supervised by the pedagogical supervisor K. Hammer úr Skúoy and the department supervisor K. Jørgensen. 


\section{The teaching scenario}

The program of the exercise was completely changed based on student feedback from the previous year and because a new teacher was responsible for the exercise. The experimental work was spread over three days with a gap of six days between the first two days and the last day of the exercise. The new exercise comprised three individual experimental approaches using the same biological material with specific work step sequences for each approach. Analyzing the same biological material allows correlation of results derived from these different approaches.

Based on the intended learning outcomes (ILOs) specified for the whole course, the teacher defined specific ILOs for this exercise. The basic aim of the exercise was that the students are able to perform and understand the methods used in the exercise and to connect the individual work steps, i.e. keeping track of experimental work over several days. Furthermore, they should understand the results, including a basic interpretation, and understand the theoretical background of the methods. Ideally, students should also be able to judge the value of the obtained results, correlate the obtained results with each other, and subsequently make an advanced interpretation of the results. Finally, they should be able to apply the newly gained knowledge to decide which methods to use to address scientific problems in a specific way.

\section{A co-constructed flowchart as a tool}

In the preparation phase, the teacher and supervisors identified specific time-points in the exercise to be observed to facilitate student understanding and learning, which may be challenging due to the stretched structure of the exercise. To ensure a good learning environment and experience, it was crucial to initially determine the level of preparation of the students to ensure a minimum level of preparation in the beginning and on each individual day of the exercise. In addition, to keep track of the students' progress and to support them in an appropriate and dynamic way throughout the exercise, the practical work had to be managed (in time), and to understand the basic underlying principles in the context of the whole exercise. Facilitating this will subsequently support the students in achieving the aims of the exercise in the context of the whole course.

To support student understanding and learning, the implementation of a flowchart illustrating the whole exercise was intended, co-constructed in dialogue with the students on a whiteboard in class. Thus, the teacher developed a layout of a respective flowchart (Fig. 1) and an initial implementation plan (Table 1) for this exercise. The flowchart consists of three sections and includes the individual work steps of the exercise. The first section is given at the beginning of the exercise on the first day and presents the problem statement, i.e., the description of the source material and the scientific problem to be addressed. The second section describes the distribution of individual tasks over the course of the exercise and the connection of individual experimental approaches. According to the implementation plan, this part is co-constructed on the first day of the exercise and referred to during recapitulation and wrap-up sessions on the following days. The co-construction is done in a plenum discussion with the students about the content of the exercise, addressing the analyzed material, the methods used and the aim of the exercise. Within one week prior to the first day of the exercise, the students received written instructions containing all essential information on these aspects of the exercise, which allowed them to prepare for the exercise. By moderating and guiding the discussion, the teacher drew the flowchart on the whiteboard 
step by step according to the students' input. Following the same approach, the third section is also co-constructed with the students on the first and second day of the exercise. It represents the expected results, their value, and connection with each other.

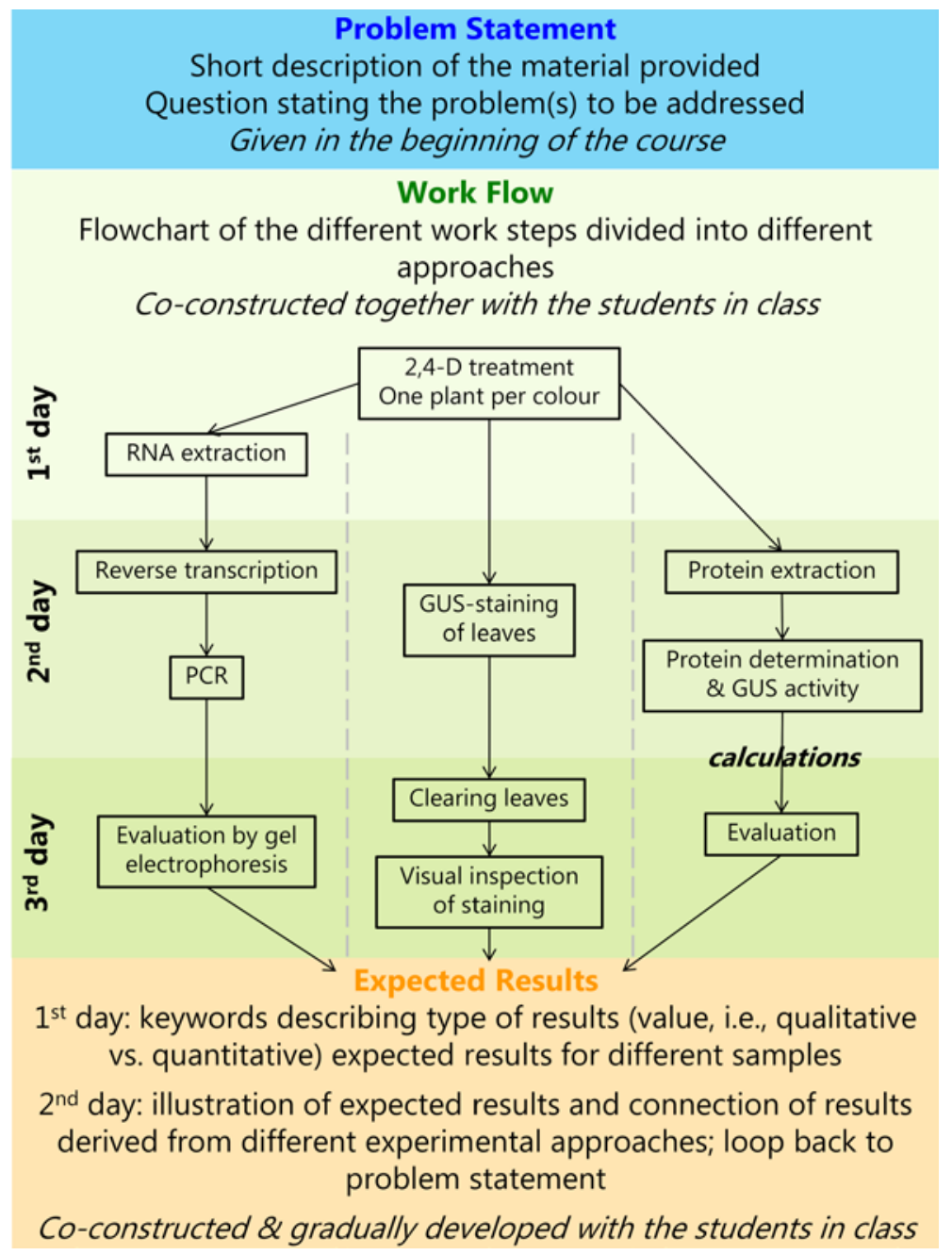

Figure 1. Outline of the flowchart as a central part of a practical exercise spread over several days. The flowchart consists of three sections and includes the individual work steps of the exercise, which are spread over several days. The first section is given at the beginning of the exercise and presents the problem statement (blue). The second section describes the distribution of individual tasks over the course of the exercise, exemplified by the work steps of the laboratory exercise "Tracking Gene Expression" in the BSc course "Plant Genomics" (green). In this example, the work is spread over three course days and split into three approaches, leading to results of different values, which are addressed in the third section, which shows the expected results (orange). The second and third sections are constructed with the students during the exercise. 
Table 1. Implementation plan for the flowchart as a central element of this laboratory exercise.

\begin{tabular}{|c|c|c|}
\hline Section & Action(s) & Intended effect \\
\hline \multicolumn{3}{|l|}{ Day 1} \\
\hline $\begin{array}{l}\text { Problem } \\
\text { Statement }\end{array}$ & $\begin{array}{l}\text { Questions and discussion on } \\
\text { source material and scientific } \\
\text { problem in plenum. } \\
\text { If no answers are given, buzz } \\
\text { groups are initiated followed by } \\
\text { plenum discussion. }\end{array}$ & $\begin{array}{l}\text { Familiarize students with the exercise } \\
\text { basics } \rightarrow \text { avoids losing students due to } \\
\text { lack of initial understanding. } \\
\text { Teacher can estimate the level of } \\
\text { understanding and preparation of the } \\
\text { students. }\end{array}$ \\
\hline Work Flow & $\begin{array}{l}\text { Teacher guides through the } \\
\text { different approaches, thereby } \\
\text { develops individual work step } \\
\text { sequences in dialogue with the } \\
\text { students. } \\
\text { Includes questions targeting } \\
\text { student understanding, i.e., } \\
\text { question-answer sequences, } \\
\text { buzz groups, and discussions in } \\
\text { plenum. }\end{array}$ & $\begin{array}{l}\text { Familiarize unprepared students with the } \\
\text { content, recapitulate content for } \\
\text { prepared students, and put the different } \\
\text { work steps into context. } \\
\text { Overview of the upcoming workload. }\end{array}$ \\
\hline $\begin{array}{l}\text { Expected } \\
\text { Results }\end{array}$ & $\begin{array}{l}\text { Questions on expectations } \\
\text { regarding results of the } \\
\text { individual approaches and their } \\
\text { value; can be supported by buzz } \\
\text { groups and plenum discussion. } \\
\text { Adding keywords to the } \\
\text { flowchart based on answers. }\end{array}$ & $\begin{array}{l}\text { Teacher can estimate the students' } \\
\text { understanding of the exercise concept } \\
\text { and which parts need special attention. } \\
\text { Short overview of the results before } \\
\text { starting the practical work. }\end{array}$ \\
\hline \multicolumn{3}{|c|}{ Start of day 2} \\
\hline $\begin{array}{l}\text { Problem } \\
\text { Statement }\end{array}$ & $\begin{array}{l}\text { Questions on the starting point } \\
\text { of the exercise and scientific } \\
\text { problem. }\end{array}$ & $\begin{array}{l}\text { Recapitulation of the exercise framework } \\
\text { to set the scene and the focus of the } \\
\text { students. } \\
\text { Teacher can check the understanding of } \\
\text { the concept. }\end{array}$ \\
\hline Work Flow & $\begin{array}{l}\text { Questions on the different } \\
\text { approaches and the current } \\
\text { progress, i.e., What has been } \\
\text { done so far? What will be done } \\
\text { on that day? }\end{array}$ & $\begin{array}{l}\text { Recapitulation of previous work and } \\
\text { awareness/ preparation of the work to be } \\
\text { performed on this day. } \\
\text { Connection of the work steps conducted } \\
\text { on different days. }\end{array}$ \\
\hline
\end{tabular}




\begin{tabular}{|c|c|c|}
\hline \multicolumn{3}{|c|}{ End of day 2} \\
\hline $\begin{array}{l}\text { Expected } \\
\text { Results }\end{array}$ & $\begin{array}{l}\text { Refining the expected results } \\
\text { through illustrations depicting } \\
\text { the specific results that will be } \\
\text { obtain, e.g., color staining. }\end{array}$ & $\begin{array}{l}\text { Supports understanding and } \\
\text { interpretation of the results. } \\
\text { Preparation of students for the results } \\
\text { from analyses they perform(ed) } \rightarrow \\
\text { connect results with practical procedures. } \\
\text { Looping back to scientific problem, i.e., } \\
\text { why to expect certain results and what } \\
\text { they would mean } \rightarrow \text { connect results with } \\
\text { scientific problem. }\end{array}$ \\
\hline \multicolumn{3}{|c|}{ Start of day 3} \\
\hline $\begin{array}{l}\text { Problem } \\
\text { Statement }\end{array}$ & $\begin{array}{l}\text { Question whether there are } \\
\text { indications for answering the } \\
\text { problem based on primary } \\
\text { results from day } 2 \text {. }\end{array}$ & $\begin{array}{l}\text { Setting the scene; initial connection of } \\
\text { preliminary results and the scientific } \\
\text { problem. } \\
\text { Teacher can check the understanding of } \\
\text { the concept. }\end{array}$ \\
\hline Work Flow & $\begin{array}{l}\text { See day 2; extended by } \\
\text { specifically addressing unclear } \\
\text { or problematic steps/aspects } \\
\text { retrospectively. }\end{array}$ & $\begin{array}{l}\text { See day 2; extended by overall connecting } \\
\text { the previous work with the last work } \\
\text { steps and upcoming results. }\end{array}$ \\
\hline \multicolumn{3}{|c|}{ End of day 3} \\
\hline $\begin{array}{l}\text { Expected } \\
\text { Results }\end{array}$ & $\begin{array}{l}\text { Guided cross-check of expected } \\
\text { vs. obtained results. } \\
\text { Discussion of the results and } \\
\text { their value. }\end{array}$ & $\begin{array}{l}\text { Validation of results. Clarification of } \\
\text { unexpected results. } \\
\text { Interpretation of results, connecting the } \\
\text { information obtained by individual } \\
\text { approaches. }\end{array}$ \\
\hline All sections & $\begin{array}{l}\text { Final plenum discussion and } \\
\text { recapitulation. }\end{array}$ & $\begin{array}{l}\text { Connect scientific problem, methods, and } \\
\text { results with the aims of the exercise to } \\
\text { facilitate a holistic understanding. } \\
\text { Highlight the need and value of the } \\
\text { different approaches, i.e., which to } \\
\text { choose to obtain what kind of } \\
\text { information to solve a certain scientific } \\
\text { problem. } \\
\text { Clarify problematic issues connected to } \\
\text { the exercise. }\end{array}$ \\
\hline
\end{tabular}




\begin{tabular}{|l|l|l|}
\hline \multicolumn{2}{|l|}{ All through the exercise } \\
\hline All sections & $\begin{array}{l}\text { Spontaneous discussions } \\
\text { between teacher and students } \\
\text { or between students based on } \\
\text { the flowchart. } \\
\text { Individual students "consulting" } \\
\text { the flowchart. }\end{array}$ & $\begin{array}{l}\text { Reference point for orientation for } \\
\text { students during the progress of the } \\
\text { exercise and for exchange/discussions. }\end{array}$ \\
\hline
\end{tabular}

Evaluation of the effects of implementing the co-constructed flowchart

One important aspect is the perception of the flowchart by the students and their evaluation of the exercise. Considering the fact that this exercise was conducted the first time with this content, it was the intention to get a very open basic feedback (via anonymous online questionnaire or by email) on the exercise, for example, what the students experienced as (very) positive or what needs to be improved. Therefore, to avoid any bias in the general evaluation of the exercise, no specific evaluation of the flowchart and its implementation was requested.

In addition to student feedback, the effect of implementing a co-constructed flowchart as a central element of the exercise was evaluated by the teacher based on experiences from previous teaching of similar exercises. Important aspects of this evaluation comprise the estimation of student understanding of the content based on the final discussion of obtained results and case studies, the quality of final reports submitted by the students, and the teacher's role and perspective on the exercise compared to similar exercises not using this tool.

\section{Results}

\section{The co-constructed flowchart facilitates active communication and orientation}

The concept of co-constructing a flowchart with the students turned out to also be very valuable in initiating dialogue with the students. The exercise started with a discussion on the basic scientific question and source material (Table 1). It was a natural process to allow students to discuss in buzz groups when the students appeared reluctant to answer the questions due to different reasons such as lack of preparation, limited initial understanding of the topic, and possibly initial reservations to speak in plenum. This initial phase of restraint was quickly overcome, and when jointly developing the work step sequences it became a relatively lively and interactive process between the teacher and the students. Thus, the coconstructed flowchart (Fig. 2) was a good initiation of the exercise by facilitating the interaction between the teacher and the students. 


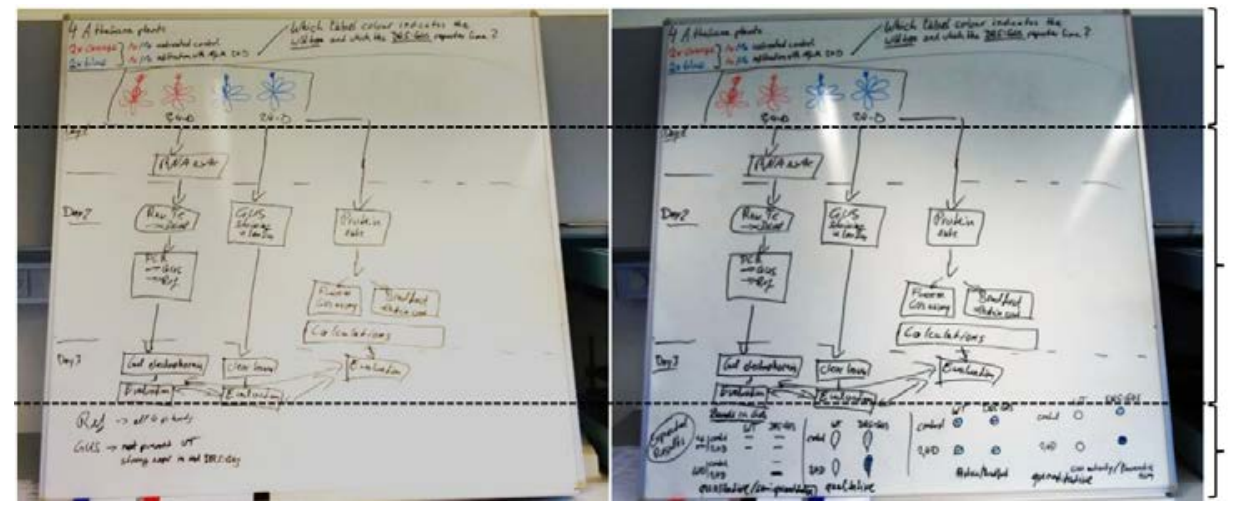

Section I

Problem statement

Section II

Work flow spread over

several days

Practical and theoretical

work including data

evaluation and linking

approaches

Section III

Expected results

[developed during course]

Figure 2. Flowchart co-constructed with the students in class. The picture shows the flowchart after day 1 (left panel), and the finalized flowchart after day 2 (right panel) with the three sections corresponding to the scheme depicted in Fig.1.

According to the implementation plan (Table 1), the flowchart served as a reference and communication tool throughout the exercise on the following days. Through recapitulation, discussion and developing the content of the exercise based on the flowchart, the students could easily connect individual work steps and follow their progress within the work sequence over the days of the exercise. As assumed, the overview of the "Expected Results" on the first day was somewhat limited as the students lacked a connection to the work steps, which they had not performed yet. When completing this section on the second day (Fig. 3), it was obvious that priming this part on the first day was very beneficial for the students' understanding. The students understood the added information very well and could easily connect it to the previous information and the other parts of the flowchart.

In general, the flowchart served as a common basis for communication of the content of the exercise between the teacher and the students, but also between individual students. In addition, it was observed that students actively used the flowchart for their orientation. It also improved the teacher's confidence as the work with the flowchart resulted in a good overview of the status and progress of the students. It created a feeling of control, but also flexibility in running the exercise. Thus, the flowchart on the whiteboard and its coconstruction with the students facilitated a good "scientific" exchange between all participants in the exercise (including the teacher) as well as the understanding of the content and the discussion partner.

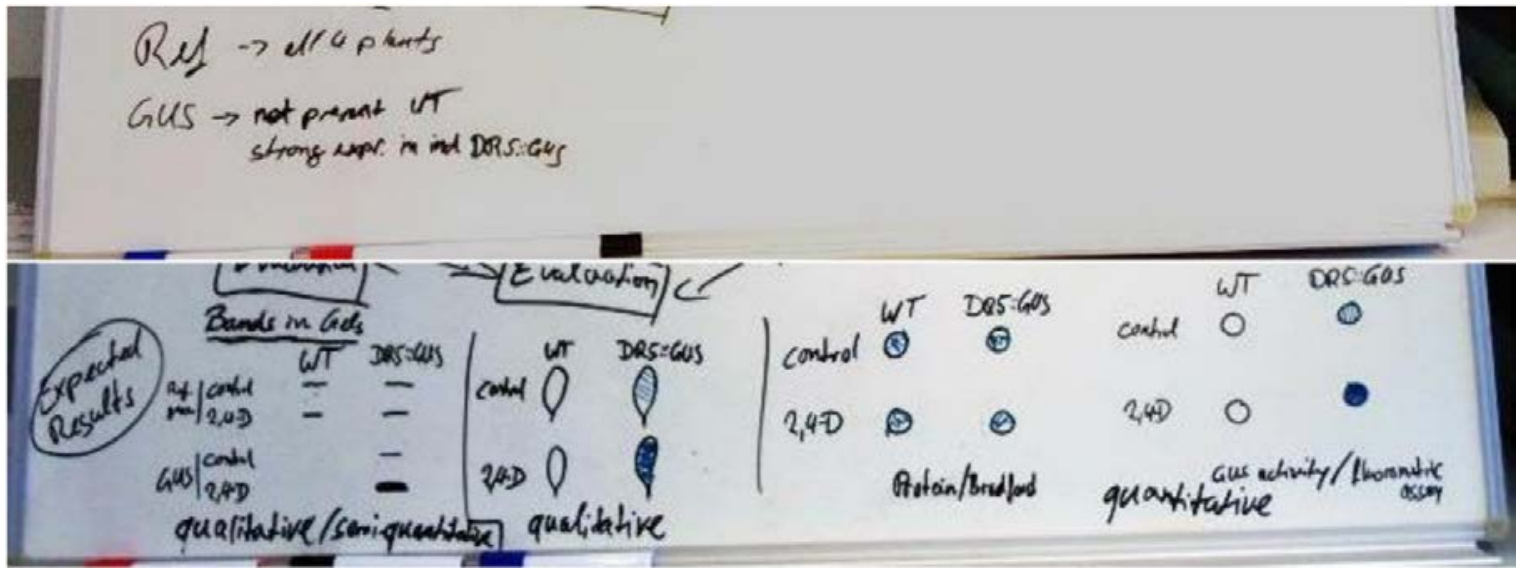


Figure 3. Close-up of section III - "Expected Results" of the flowchart. The upper panel shows the expected results as short keywords after day 1, the lower panel shows the depiction of the results after co-constructing this section with the students on day 2 after recapitulating the work progress up to that point. A more detailed description of the expected results was possible on day 2 of the exercise after the students were more familiar with the content of the exercise and had time to reflect on it and the expected results.

\section{Success of the flowchart-centered exercise}

A central part of estimating the success of the exercise in terms of the students achieving the learning goals was a closing discussion session. Their results and selected research publications, which are based on the methods performed in the exercise, were discussed in plenum. Overall, the students were very well aware of the work they performed, and the meaning and value of the results, as evidenced by the quality of their active contributions to the discussions and constructive and conscious questions, as well as the involvement in the discussion of the majority of the students. They were able to recapitulate the individual methods, what they are useful for, and how they may complement each other. Furthermore, they could explain how the different results are connected, and how they may be combined to answer scientific questions. When discussing the case studies, the students were able to apply their knowledge of the learned methods to the presented research. While the basic understanding of their own work was much better than experienced in similar courses, it was the first time the teacher could say that the students were able to apply their knowledge to other scientific contexts. In previous courses, this turned out to be a very critical aspect, which is probably connected to the observed lack of basic understanding. Similarly, the high level of understanding was also reflected in the final reports, which on average were of a better quality and showed more depth of understanding of the ILOs than experienced before. Importantly, no group failed to describe the work performed, to present the results and to provide valid interpretation, which regularly happened in similar exercises before. This means that generally all intended learning goals of the exercise had been achieved, which was not always the case in previous courses. Instead, the final discussion and the reports highlighted very specific details the students struggled with, which may have otherwise stayed hidden through the lack of a basic understanding of the exercise content.

\section{Students' appreciation of the flowchart}

During the exercise feedback, some students indicated that they appreciate this approach, having the flowchart developed together step by step on a whiteboard that stays in the laboratory. In addition, the flowchart was often highlighted as a very positive aspect in the feedback provided by the students after completing the exercise. They were initially simply asked for feedback on aspects they perceived as positive and those that could be improved. Eight out of eleven students provided feedback of which seven specifically mentioned the flowchart/whiteboard as the most (or one of the two most) positive aspects of the exercise, while one student referred to it indirectly (Table 2). This positive evaluation after class confirmed the very positive impression during the course of the exercise. 
Table 2. Compiled original feedback referring to the used flowchart/whiteboard provided by students after class.

\begin{tabular}{|c|c|c|}
\hline \multirow[t]{3}{*}{$\begin{array}{l}\text { Responses by } \\
\text { email }\end{array}$} & Student 1 & $\begin{array}{l}\text { Positive: Overview on whiteboard, nice } \\
\text { structure of exercise }\end{array}$ \\
\hline & Student 2 & $\begin{array}{l}\text { I really liked the flow chart and that you } \\
\text { went through it so thoroughly. It gives a } \\
\text { very good overview combined with the } \\
\text { protocol. }\end{array}$ \\
\hline & Student 3 & $\begin{array}{l}\text { Positive: - Great with introduction to the } \\
\text { experiment with board overview, but don't } \\
\text { expect the students to have read for the } \\
\text { next many lab days, usually we only read } \\
\text { the stuff we are supposed to do for the day. }\end{array}$ \\
\hline \multirow[t]{5}{*}{$\begin{array}{l}\text { Anonymous } \\
\text { responses via } \\
\text { online } \\
\text { questionnaire }\end{array}$} & Student 4 & $\begin{array}{l}\text { I like the way you used the whiteboard to } \\
\text { tell about the different results in the } \\
\text { exercise. That made a good brush-up and } \\
\text { was along a good learning point. }\end{array}$ \\
\hline & Student 5 & White board layout, nice structure \\
\hline & Student 6 & Great with board overview before exercise \\
\hline & Student 7 [commented] & $\begin{array}{l}\text { The exercise was well described in the lab } \\
\text { by Dominik, so there was no confusion. He } \\
\text { was also very good at asking questions, so } \\
\text { you had to think about some aspect you } \\
\text { might not have thought about. } \\
\text { Comment by D. K. Grosskinsky (teacher): As } \\
\text { these points were performed with the use of } \\
\text { the flowchart/whiteboard, this feedback can } \\
\text { be regarded as a positive evaluation of this } \\
\text { tool. }\end{array}$ \\
\hline & Student 8 & $\begin{array}{l}\text { The flow-chart and the run-through created } \\
\text { a nice overview of the exercise (very } \\
\text { pedagogical) }\end{array}$ \\
\hline
\end{tabular}

Students were asked to provide feedback on positive aspects and points of potential improvement of the whole practical exercise in general. All original, unedited feedback related to the flowchart is included in the table.

The flowchart from an external observer's view

As part of the teacher's pedagogical education, the co-construction and implementation of the flowchart in this exercise were accompanied by two experienced teachers as external observers. Overall, the described flowchart-based approach contributed to a very wellplanned teaching session which incorporated varied activities. While discussions and buzz 
meetings were centered on the use of the flowchart, the flowchart turned out to be an elegant way to link the theoretical and practical teaching activities to ensure progress towards reaching the planned overall objectives in this part of the course. This has been set up to make a way for the students to internalize the theoretical part of their study program. In addition, the flowchart served as an anchor for the teacher to change his teacher role with effortless ease. The various activities incorporating the flowchart allowed for a real-time formative assessment of the students' progress and direct feedback to current questions, even supporting differentiated teaching based on the students' different starting points and progress during the session.

Thus, the external observations match the positive experience described by the teacher and the students. The co-construction and subsequent repeated use of the flowchart strongly supported the students' learning process and created a very fruitful and safe learning environment, motivating the students to actively engage in their own learning. It was observed that the students also visited the flowchart in between the laboratory exercise as a tool to keep track of the different activities and to discuss in the group. On asking the students, they commented that it had been a constructive way to get an overview of what they should do and had already done to keep track of the learning in this exercise. In summary, the developed flowchart and its implementation, a flowchart to which everyone contributes, strongly supported the students in structuring their laboratory work.

\section{Discussion}

The co-constructed flowchart as a supporting tool for student learning

The implementation of the co-constructed flowchart very much supported the students in achieving the primary aims of the exercise. While the joint construction in itself facilitated the preparation of the students and their active contribution to creating the illustration of the framework, the final flowchart served as a common reference point throughout the course of the exercise. Based on the fact that the flowchart was jointly constructed, the students could also claim ownership, i.e., they could relate to it more easily than if it were just presented by the teacher. Furthermore, this flowchart allowed the different experimental approaches, which were followed in parallel, to be interconnected. The illustration itself may have a beneficial effect, as individuals may grasp the concept more easily from this than just from text. In addition, the integrated repetitive elements in the implementation plan, i.e., that individual points are discussed and recapitulated several times from slightly changing perspectives, appears very beneficial in increasing the understanding of the students and internalizing the obtained knowledge.

Because achieving the primary aims of the exercise was not a problem in contrast to previous courses, this approach revealed the specific problems students are commonly struggling with. In cases where students are struggling with the basic primary aims of such exercises, these specifically problematic aspects may be hidden and not addressed in an appropriate way. These points were very specific, but apparently did not limit the understanding of the basic concepts. In contrast, the overall understanding of the students corresponded to a relational qualitative level of the SOLO-taxonomy of understanding (Mørcke \& Rump, 2015), which therefore was on a higher level than in previous courses. Furthermore, the feedback provided by the students clearly demonstrated their appreciation, as it apparently supported their understanding and learning, which is in agreement with the use of student-generated flowcharts in chemistry laboratory exercises (Davidowitz \& Rollnick, 
$2001,2003)$. This seems more important than the use of modern high-tech tools, which is in agreement with studies on preferred teaching techniques of natural science and medical students (Novelli \& Fernandes, 2007; Waheeda \& Murthy, 2015).

The co-constructed flowchart as a supporting tool for the teacher

The flowchart also provided a good basis for the teacher to facilitate a supportive interaction with the students. It helped in monitoring and guiding the progress of the students, regularly providing feedback, and getting the exercise back on track, e.g., when time was running short, as no big explanations were needed when referring to an already known scheme. The flowchart was also a good tool for the teacher to shift between different roles to diversify the teaching-learning environment (Beck \& Gottlieb, 2002). When constructing the flowchart or referring to it as a common basis during daily recapitulation and discussions, the teacher had the chance to move from his role as a coach or supervisor during the practical work to the role of a participant in the discussion or functions as a moderator (Beck \& Gottlieb, 2002). This diversified teacher role appeared to be a suitable way to adjust the teaching-learning environment in relation to different needs and it also seemed to be beneficial for the resulting understanding of the students. As the flowchart eased the interaction and communication between teacher and students in general regarding the scientific content of the exercise, it can be a simple tool to spur a kind of research-tutored teaching (Healey \& Jenkins, 2005). This allows the teacher to easily refer to the practical work of the exercise in the context of higher scientific concepts or research questions to spur students' ability to transfer the learned methods to different scenarios.

\section{Conclusion}

In this specific laboratory exercise, the use of a co-constructed flowchart appeared to be a valuable approach to guiding the students through the stretched structure of the program, keeping track of their progress, supporting their understanding and learning, and forming the basis for discussions. The implementation of the flowchart had a beneficial impact on different aspects of the teaching-learning environment and can thus be regarded as a success. However, it is important that a teacher defines the purpose of the flowchart for a specific teaching unit and subsequently, how an appropriate flowchart has to look and how it has to be implemented according to a suitable plan, taking the teaching situation into consideration. This means that a specific flowchart could simply be provided as a guide or could be created either through co-construction (like here) or by the students on their own, followed by feedback on their drafts. Certainly, the latter options have the advantage that students have to deal with the content of teaching and develop a feeling of ownership by contributing to the flowchart construction. With these considerations, flowcharts seem to be good tools for guiding students through exercises and content with a complex structure.

\section{Acknowledgement}

Valuable feedback during the preparation of the manuscript by Frederik V. Christiansen and Vibeke Langer (University of Copenhagen) is gratefully acknowledged.

\section{References}

Beck, S., \& Gottlieb, B. (2002). Elev/student - en teoretisk og empirisk undersøgelse af begrebet studiekompetence. Gymnasiepaedagogik, Nr. 31, Institut for 
Kulturvidenskaber, Syddansk Universitet.

Davidowitz, B., \& Rollnick, M. (2001). Effectiveness of flow diagrams as a strategy for learning in laboratories. The Australian Journal of Education in Chemistry 57 (1), 18-24.

Davidowitz, B., \& Rollnick, M. (2003). Enabling metacognition in the laboratory: a case study of four second year university chemistry students. Research in Science Education 33 (1), 43-69.

Grosskinsky, D. K. (2018). Tracking and supporting student learning in practical laboratory exercises spread over several days. In Christiansen F. V., \& Prestholm, I. (Eds.), Improving University Science Teaching and Learning - Pedagogical Projects 2018, pp 4761. Copenhagen: Department of Science Education, University of Copenhagen.

Healey, M., \& Jenkins, A. (2005). Developing undergraduate research and inquiry. York: The Higher Education Academy

Hofstein, A., \& Lunetta, V. N. (2004). The laboratory in science education: foundations for the twenty-first century. Science Education 88 (1), 28-54.

Hofstein, A., \& Mamlok-Naaman, R. (2007). The laboratory in science education: the state of the art. Chemistry Education Research and Practice 8 (2), 105-107.

Mørcke, A. M., \& Rump, C. Ø. (2015). University teaching and learning - models and concepts. In Rienecker, L., Jørgensen, P. S., Dolin, J., \& Ingerslev, G. H. (Eds.), University Teaching and Learning, pp. 93-104. Frederiksberg: Samfundslitteratur.

Novelli, E. L. B., \& Fernandes, A. A. H. (2007). Students' preferred teaching techniques for biochemistry in biomedicine and medicine courses. Biochemistry and Molecular Biology Education 39 (4), 263-266.

Reid, N., \& Shah, I. (2007). The role of laboratory work in university chemistry. Chemistry Education Research and Practice 8 (2), 172-185.

Tanner, K., \& Allen, D. (2004). Approaches to biology teaching and learning: learning styles and the problem of instructional selection - engaging all students in science courses. Cell Biology Education 3 (4), 197-201.

Waheeda, S., \& Murthy, K. S. (2015). A comparative study of blackboard teaching with PowerPoint teaching in 1 year medical students. National Journal of Basic Medical Sciences $6(1), 11-13$. 